\title{
Spectrophotometric Determination of Erdosteine at Capsule Dosage Forms
}

\section{Erdostein'in Kapsül Dozaj Formlarında Spektrofotometrik Olarak Analizi}

\author{
(D) Cem ÖNAL 1,2 , iD Demet DINÇEL 3
}

${ }^{1}$ Cinnagen Medicine Company, Project Director, İstanbul, Turkey

2İstanbul Health and Technology University Faculty of Pharmacy, Department of Analytical Chemistry, İstanbul, Turkey

${ }^{3}$ Bezmialem Vakıf University Faculty of Pharmacy, Department of Analytical Chemistry, İstanbul, Turkey

\section{ABSTRACT}

Objective: Two simple, rapid and sensitive methods were developed for determination of Erdosteine (ERD) in pure form as well as in their pharmaceutical formulations.

Methods: The methods were based on formation of colored charge transfer complexes with ERD with chloranil (CA) and 7,7,8,8-tetracyanoquinodimethane (TCNQ). The obtained charge-transfer complexes were measured at 454 and $843 \mathrm{~nm}$ for CA and TCNQ methods, respectively. Optimization of different experimental conditions were investigated.

Results: Beer's plots were obeyed in a general concentration range of 10-500 $\mu \mathrm{g} \mathrm{mL}^{-1}$ and 20-600 $\mu \mathrm{g} \mathrm{mL}^{-1}$ for CA and TCNQ methods, respectively. The validity of methods in terms of specificity, linearity, accuracy, precision, limit of detection and limit of quantitation were evaluated.

Conclusion: The methods were applied successfully in the determination of ERD in capsule dosage forms. Developed new spectrophotometric methods have been found to be very practical and practical. The lack of complex sample preparation increases the applicability of the method.

Keywords: Erdosteine, charge transfer complex, TCNQ, CA, spectrophotometry, validation, pharmaceutical formulation

\section{ÖZ}

Amaç: Erdostein'in (ERD) farmasötik formülasyonlarında tayini için iki basit, hızlı ve hassas yöntem geliştirilmiştir.

Yöntemler: Metotların esası, kloranil (CA) ve 7,7,8,8-tetrasiyanokinodimetan (TCNQ) ile ERD arasında renkli yük transfer komplekslerinin oluşturulmasına dayanmaktadır. Maksimum dalga boyları CA ve TCNQ yöntemleri için sırasıyla 454 ve 843 nm'de ölçülmüştür. Deney koşullarının optimizasyonu araştırılmıştır.

Bulgular: Beer kuralı, CA ve TCNQ metotları için sırasıyla 10$500 \mu \mathrm{g} \mathrm{mL}^{-1}$ ve $20-600 \mu \mathrm{g} \mathrm{mL}^{-1}$ konsantrasyon aralığında bulundu. Yöntemler özgünlük, doğrusallık, doğruluk, kesinlik, gözlenebilme sınırı, tayin sınırı gibi validasyon parametreleri açısından değerlendirildi.

Sonuç: Metodlar ayrıca ilaç içeren kapsüllerde ERD'nin tayininde de başarıyla uygulandı. Geliştirilen yeni spektrofotometrik metotların oldukça pratik ve uygulanabilir olduğu belirlenmiştir. Örnek hazırlama aşamasında karmaşık numune hazırlama işlemlerine gereksinim duyulmaması yöntemin uygulanabilirliğini artırmaktadır.

Anahtar Sözcükler: Erdostein, yük transfer kompleksi, TCNQ, CA, spektrofotometri, validasyon, farmasötik formülasyon

Address for Correspondence: Cem ÖNAL, Cinnagen Medicine Company, Project Director, İstanbul, Turkey

E-mail: cemfox@yahoo.com ORCID ID: orcid.org/ 0000-0002-5840-7386 


\section{Introduction}

Erdosteine (ERD), a potent mucolytic agent, shows pharmacological activity by lowering the viscosity of mucus in the respiratory system and thus reducing the ability of the bacteria to adhere to the cellular membrane. ERD has antiinflammatory properties in the bronchial airways and scavenges free radical compounds from the airways. Chemical structure of ERD consists of thiolactone and carboxyl group. Its chemical formula is 2- [2-oxo-2 - [(2-oxothiolan-3-yl) amino] ethyl] sulfanylacetic acid (Figure 1) (1-3).

Various analytical methods such as UV spectrophotometric method (4-8) and high performance liquid chromatography (914) have been found in the literature for the determination of ERD from pharmaceutical preparations and biological fluids. In this study, two spectrophotometric methods were proposed to determine the amount of ERD in pharmaceutical preparations using easily accessible materials and equipment. In the proposed methods, CA and tetracyanoquinodimethane (TCNQ) reagents were reacted with ERD to form charge transfer complexes (CT complexes). For quantitative analysis of pharmaceutical compounds in pharmaceutical dosage forms, the use of CA and TCNQ reagents to obtain CT complexes is preferred because they do not require a buffer, they are fast, precise and cost-effective (15-18). Therefore, in this study, we considered it appropriate to develop two methods for the analysis of ERD using these two markers, and these developed methods were successfully applied in the analysis of ERD in pharmaceutical formulations.

\section{Method}

\section{Devices}

Spectrophotometric measurements were performed using a Hitachi spectrometer Model U-2900 equipped with a xenon lamp and $1 \mathrm{~cm}$ quartz cells.

\section{Reagents and Solutions}

ERD was obtained from EnzyChem Lifesciences (Korea), TCNQ Fluka (Neu-Ulm, Germany) and CA Merck (Darmstadt, Germany). The pharmaceutical preparation (ERDOSTIN ${ }^{\circledR} 300$ $\mathrm{mg}$ ) was obtained from the pharmacy. All chemicals and reagents were used for analytical purity.

\section{Stock Solutions}

Stock solutions of ERD were prepared in methanol to make up 1 $\mathrm{mg} / \mathrm{mL}$. Solutions of $0.2 \%(\mathrm{w} / \mathrm{v})$ for TCNQ and $0.2 \%(\mathrm{w} / \mathrm{v})$ for $\mathrm{CA}$ were prepared in acetonitrile. The solutions were determined to be stable for 1 week at $4{ }^{\circ} \mathrm{C}$.

\section{General Analysis Method}

ERD stock solution in volumes of $0.050-2.5 \mathrm{~mL}$ and 0.100 $3.0 \mathrm{~mL}$ was added to $5 \mathrm{~mL}$ calibrated flasks for CA and TCNQ methods, respectively. The volume of the stock solutions in each flask was brought to $2.5 \mathrm{~mL}$ with acetonitrile for the CA method and $3.0 \mathrm{~mL}$ for the TCNQ method, and $0.75 \mathrm{~mL} \mathrm{CA}$ and $1 \mathrm{~mL}$ TCNQ reagents were added to them. The reaction mixture was heated at $80^{\circ} \mathrm{C}$ for $5 \mathrm{~min}$ for the TCNQ method and then stood at room temperature for $5 \mathrm{~min}$ for $\mathrm{CA}$. After the cooling process, it was diluted to $5 \mathrm{~mL}$ with methanol and its absorbance was measured against the blank test at 454 and $843 \mathrm{~nm}$ for CA and TCNQ methods, respectively. Calibration charts were prepared by measuring the absorbance against the ERD concentration.

\section{Analysis Method for Capsules}

The amount equivalent to $300 \mathrm{mg}$ ERD was weighed and dissolved in $125 \mathrm{~mL}$ of methanol. Then it was extracted in a mechanical mixer for 20 minutes and in an ultrasonic bath for 20 minutes. The volume was made up to $250 \mathrm{~mL}$ and then filtered through filter paper. The filtrate was diluted with methanol and studied as in the preparation of the calibration curve. The amount of substance in the capsule was measured using the calibration graph and the corresponding regression equation.

\section{Results}

The maximum absorption of the CT complexes obtained as a result of the reaction formed by ERD with CA and TCNQ reagents was observed at 454 and $843 \mathrm{~nm}$, respectively (Figure 2).

Optimum conditions such as reaction time, temperature, type of solvent, amount of reagents used and reaction stoichiometry were also investigated for the reaction, which were explained in detail below.

\section{Choosing the Most Suitable Solvent}

Various solvents commonly used in analytical procedures including acetonitrile, chloroform, methanol, acetone, ethanol, 1,4-dioxane and methylene chloride were used to determine

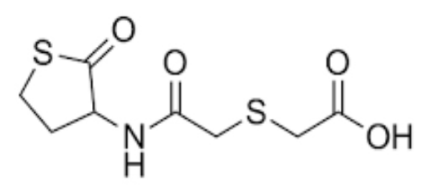

Figure 1. Chemical structure of Erdosteine

(A)
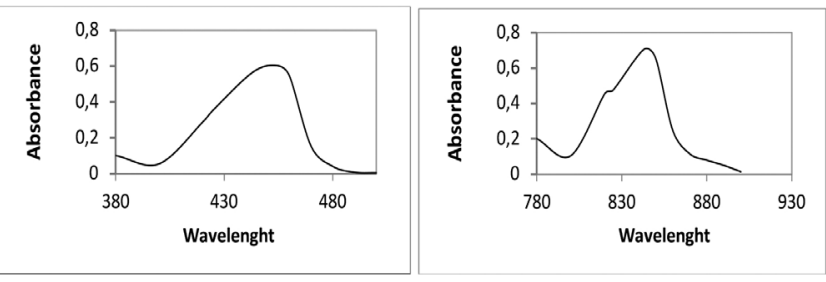

Figure 2. (A) Absorption spectrum of ERD-CA complex against blank solution (400 $\mathrm{\mu g} \mathrm{mL}-1)$ (B) Absorption spectrum of ERD-TCNQ complex against blank solution (600 $\mu \mathrm{gL}-1)$

CA: Chloranil, TCNQ: Tetracyanoquinodimethane, ERD: Erdosteine 
the most suitable solvent. It was observed that the most suitable solvent was obtained by using methanol.

\section{Reagent Concentration}

The optimum reagent concentration was investigated by changing the concentrations of TCNQ and CA reagents and keeping the ERD concentration constant. As shown in the figure, the optimum reagent amount was $0.75 \mathrm{~mL} \mathrm{CA}[0.2 \%$ (w/v)] and $1.0 \mathrm{~mL} \mathrm{TCNQ} \mathrm{[0.2 \%} \mathrm{(w/v)]} \mathrm{(Figure} \mathrm{3).}$

\section{Reaction Time}

The time required to complete the reaction between ERD and CA and TCNQ was studied spectrophotometrically at room temperature and $60-80{ }^{\circ} \mathrm{C}$, respectively. A reproducible color development was achieved in 5 minutes for CA and TCNQ, respectively, at room temperature and $80{ }^{\circ} \mathrm{C}$. The color reaction resulting from the CT complexes was observed stably for 12 hours (Figure 4).

\section{Reaction Stoichiometry}

Job's continuous change method was used for the reaction stoichiometry (19). According to the results, the equivalent

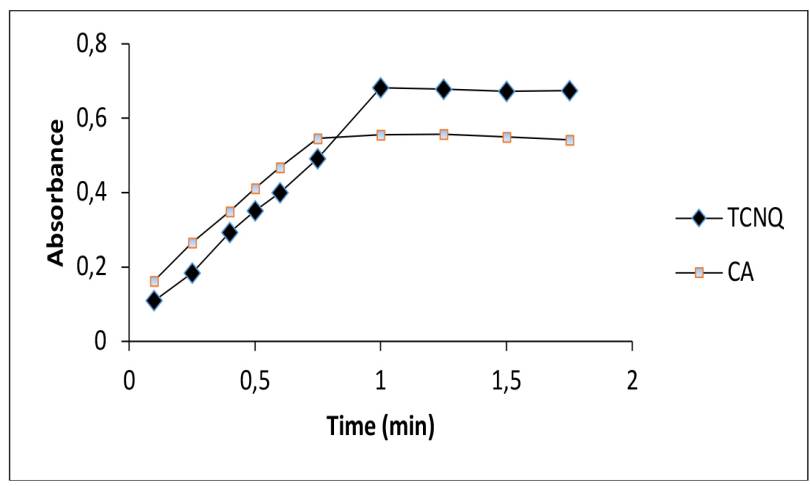

Figure 3. Effect of volumes of CA $(0.2 \%, w / v)$ and TCNQ $(0.2 \%, w / v)$ reagents on the formation of the reaction product of ERD with CA and TCNQ

CA: Chloranil, TCNQ: Tetracyanoquinodimethane, ERD: Erdosteine molarity of ERD and reagents was defined as the $1: 1$ ratio (compound/reagent).

\section{Method Validation}

The proposed analytical methods were validated according to the ICH guideline Q2 (R1) (20). Calibration curves were generated for all methods under the above conditions. Regression equation, correlation coefficients, Beer's law limits, limit of observability (LOD) and determination limit (LOQ) data for each method are given in Table 1 .

According to the results obtained, a linear correlation between 10-500 $\mu \mathrm{g} \mathrm{mL}^{-1}$ and 20-600 $\mu \mathrm{g} \mathrm{mL}^{-1}$ was observed for CA and TCNQ methods, respectively.

The formula of $\mathrm{LOD} / \mathrm{LOQ}=\kappa \mathrm{SDa} / \mathrm{b}$ was used to calculate LOD or LOQ. Here the value of is 3 for LOD and 10 for LOQ. $\mathrm{SDa}$ indicates the standard deviation of the scale curve intersept and $\mathrm{b}$ is the slope. The results are shown in Table 1.

Sensitivity values of intra-day and inter-day were examined at 50, 100 and $500 \mu \mathrm{g} / \mathrm{mL}$ for the TCNQ and CA method ( $\mathrm{n}=5$ for each) for 5 consecutive days. The \% RSD values for the inter-day precision $\%$ and the inter-day precision results for all

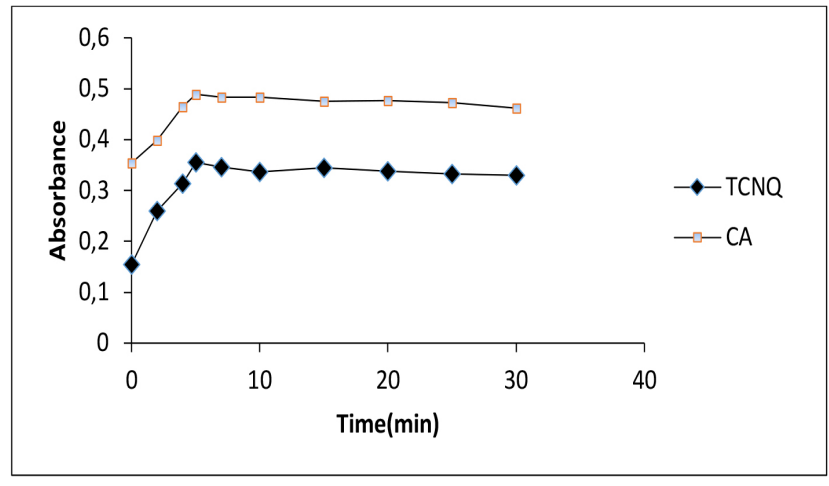

Figure 4. Effect of temperature and heating time on reaction of TCNQ (at $80^{\circ} \mathrm{C}$ ) and CA (at room temperature) reagents with ERD

CA: Chloranil, TCNQ: Tetracyanoquinodimethane, ERD: Erdosteine

Table 1. Validation parameters

\section{CA reagent}

Linear range $\left(\mu \mathrm{gL}^{-1}\right)$

Regression equation ${ }^{b}$

Slope \pm SD

Intersept \pm SD

Correlation coefficient, r

LOD ( $\mu \mathrm{g} \mathrm{mL}^{-1}$ )

LOQ $\left(\mu \mathrm{g} \mathrm{mL}^{-1}\right)$

Precision
10-500

$0.0016 \pm 0.000008$

$0.0711 \pm 0.00032$

0.9997

0.00034

0.0011

\section{TCNQ reagent}

20-600

$0.0013 \pm 0.000015$

$0.0612 \pm 0.00014$

0.9995

0.00074

0.0025

${ }^{a}$ Average of 6 studies

$\mathrm{A}=\mathrm{mC}+\mathrm{b}\left[\mathrm{C}\right.$ : Concentration $\left(\mu \mathrm{g} \mathrm{mL} \mathrm{L}^{-1}\right)$ and $\mathrm{A}$ : Absorption at $\left.\lambda_{\mathrm{max}}\right)$

SD: Standard deviation, CA: Chloranil, TCNQ: Tetracyanoquinodimethane, LOD: Limit of obsercability detection, LOQ: Limit of quantification 
proposed methods provided good reproducibility. Results are given in Table 2. The accuracy of the developed methods was examined using the standard addition technique. Pure analyte was mixed with standard solutions at 3 different concentration levels on the sample solution and analyzed. The results obtained are presented in Table 3. It was observed that the average recovery percentages calculated were $100.31 \%$ for CA and $100.82 \%$ for TCNQ, proving the method to be of high accuracy (Table 2). The methods developed were been successfully applied in the analysis of the drug substance in pharmaceutical preparations, and according to these results, no interference from additives and excipients was observed. The results are given in Table 4. Small changes were made to the method developed to test the robustness of the method and the effect of these changes on the method was examined. For this, changes in TCNQ and CA reagent concentrations $(\%, w / v \pm 0.05)$ and reaction times (optimum time $\pm 0.5 \mathrm{~min}$ ) were made, and when the results were examined in terms of recovery and RSD values, it was observed that there was no significant difference.

\section{Table 2. Precision results}

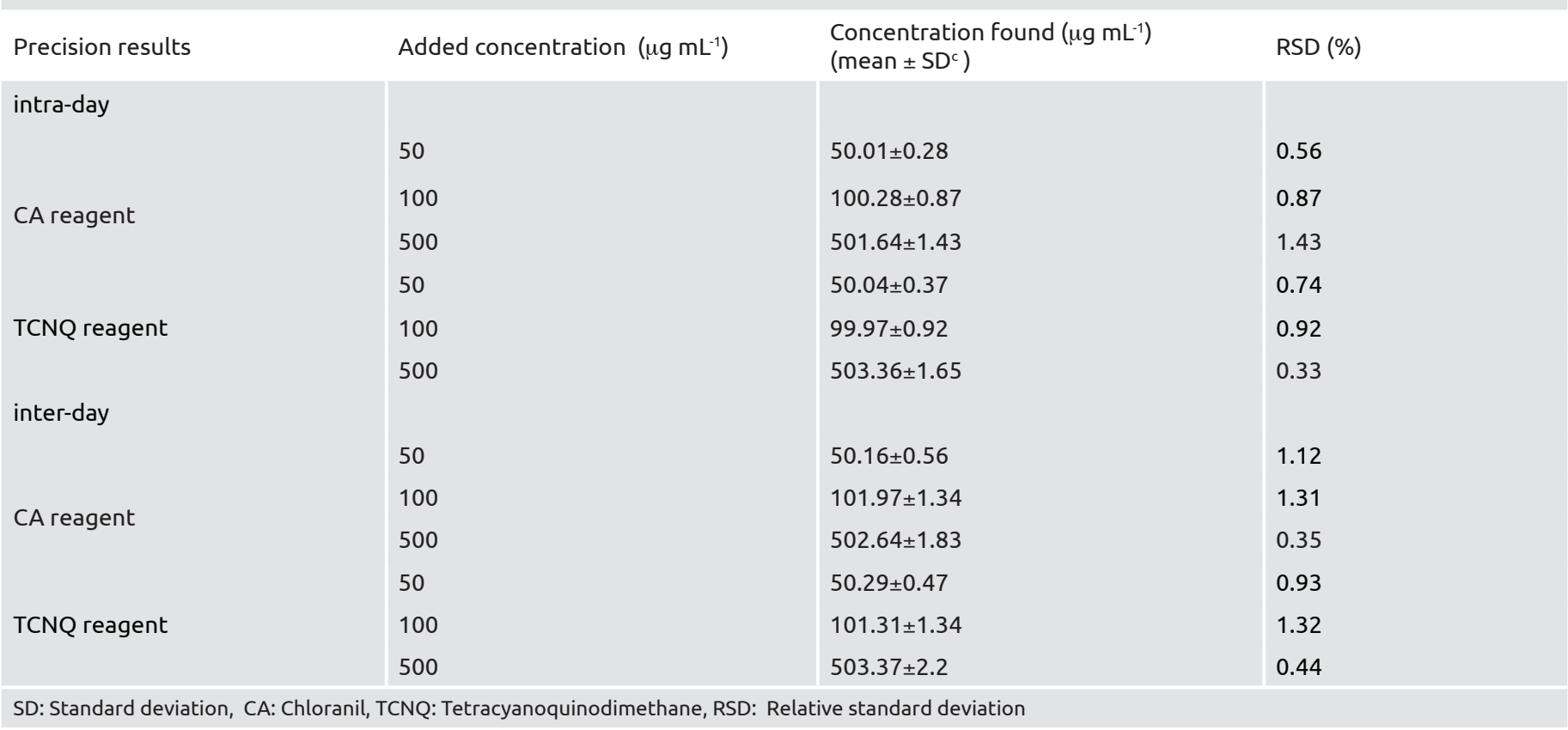

Table 3. Recovery results

\begin{tabular}{|c|c|c|c|c|c|}
\hline Method developed & $\begin{array}{l}\text { Concentration } \\
\text { taken }^{\mathrm{a}}\left(\mu \mathrm{g} \mathrm{mL}^{-1}\right)\end{array}$ & $\begin{array}{l}\text { Added concentration } \\
\left(\mu \mathrm{g} \mathrm{mL} \mathrm{L}^{-1}\right)\end{array}$ & $\begin{array}{l}\text { Concentration found } \\
\left(\mu g \mathrm{~mL}^{-1}\right) \\
\left(\mathrm{mean} \pm \mathrm{SD}^{\mathrm{c}}\right)\end{array}$ & Recovery (\%) & RSD (\% \\
\hline \multirow{4}{*}{ CA reagent } & \multirow{4}{*}{100} & 10 & $109.36 \pm 1.12$ & 99.42 & 1.02 \\
\hline & & 200 & $301.28 \pm 2.74$ & 100.43 & 0.91 \\
\hline & & 400 & $505.39 \pm 3.86$ & 101.08 & 0.76 \\
\hline & & 20 & $120.68 \pm 1.24$ & 100.57 & 1.03 \\
\hline \multirow[t]{2}{*}{ TCNQ reagent } & \multirow[t]{2}{*}{100} & 200 & $303.87 \pm 3.01$ & 101.29 & 0.99 \\
\hline & & 500 & $603.54 \pm 4.27$ & 100.59 & 0.71 \\
\hline
\end{tabular}

aERDOSTIN ${ }^{\circledR} 300 \mathrm{mg},{ }^{b} \mathrm{n}=5$, 'Standard deviation, SD: Standard deviation, RSD: Relative standard deviation, TCNQ: Tetracyanoquinodimethane

Table 4. Analysis of capsules containing $300 \mathrm{mg}$ erdosteine $(n=5)$

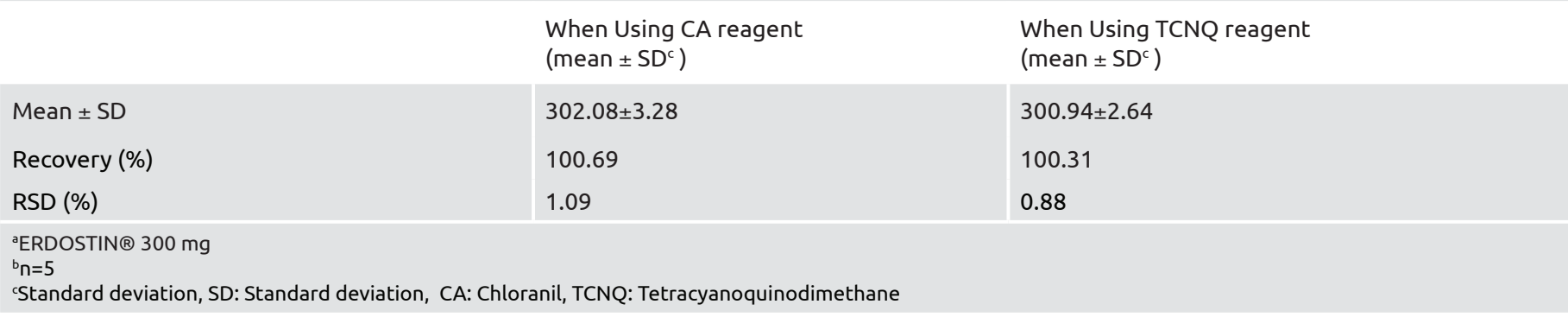




\section{Conclusion}

As a result, the new spectrophotometric methods developed are very practical and applicable. Not requiring complicated sample preparation processes before hand increases the applicability of the method. The developed methods enable the analysis of ERD in pharmaceutical preparations with high accuracy and precision. This method can be used in routine analysis of the drug.

Peer-review: Externally peer reviewed.

\section{Authorship Contributions}

Concept: C.Ö., Design: C.Ö., Data Collection or Processing: C.Ö., D.D., Analysis or Interpretation: C.Ö., D.D., Literature Search: D.D., Writing: C.Ö., D.D.

Conflict of Interest: No conflict of interest was declared by the authors.

Financial Disclosure: The authors declared that this study received no financial support.

\section{References}

1. Dechant KL, Noble S. Erdosteine. Drugs 1996;52:875-81.

2. Fumagalli G, Balzarotti C, Banfi P, Decò P, Ferrante L, Zennaro M. Erdosteine: A new molecule with mucolytic activity. Clinical and instrumental evaluation in patients with acute exacerbated chronic bronchopneumopathies. Italian J Chest Diseases 1988;42:299-308.

3. Marchioni CF, Moretti M, Muratri M, Casadei MC, Guerzoni P, Scuri R, et al. Effects of Erdosteine on Sputum Biochemical and Rheologic Properties- Pharmacokinetics in Chronic Obstructive Lung Disease. Lung 1990;168:285-93.

4. Nanda RK, Gaikwad J, Prakash A, Ghosh VK, Nagore DH. Estimation of Cefixime and Erdosteine in its Pharmaceutical Dosage Form by Spectrophotometric Method. Asian J Research Chem 2009;2:404-6.

5. Mistry N, Shah P, Chaudhari D, Baria B, Gandhi T. Simultaneous Estimation of Erdosteine, Guaiphenesin and Terbutaline Sulphate in Syrup Formulation by Two UV Spectrophotometric Methods. Indian Drugs 2017;54:46-51.

6. Moustafa NM, Badawey AM, Lamie NT, Abd El-Aleem AB. Stability-Indicating Methods for the Determination of Erdosteine in the Presence of its Acid Degradation Products. J AOAC Int 2014;97:86-93.

7. Nanda RK, Gaikwad J, Prakash A. Estimation of tamsulosin and tolterodine in its pharmaceutical dosage form by spectrophotometric method. Int J Pharm Tech Res 2009;1:420-3.
8. Dhoka MV, Gawande VT, Joshi PP, Gandhi SV, Patil NG. Simultaneous estimation of Cefixime and Erdosteine in capsule dosage form by spectrophotometric method. Hindustan Antibiot Bull 2009;51:29-32.

9. Muramatsu N, Toyo'oka T, Yamaguchi K, Kobayashi S. Highperformance liquid chromatographic determination of erdosteine and its optical active metabolite utilizing a fluorescent chiral tagging reagent, R-(-)-4-(N,N-dimethylaminosulfonyl)-7-(3aminopyrrolidin-1-yl)-2,1,3-benzoxadiazol. J Chromatogr B Biomedical Sciences and Applications 1998;719:177-89.

10. Madhura VD, Vandana TG, Pranav PJ. Simultaneous estimation of cefixime trihydrate and erdosteine in pharmaceutical dosage form by using reverse phase-high performance liquid chromatography. Int. J Chem Tech Res 2010;2:79-87.

11. Ayre AP, Pawar HA. Stability-Indicating RP-HPLC Method for Estimation of Erdosteine and its Degradation Products in Pharmaceutical Dosage Form. Journal of Pharmaceutical and Bioanalytical Science 2012;1:2-7.

12. Khan MG, Jain PS, Shirkhedkar AA, Fursule RA, Kale NK, Surana SJ. Stability indicating HPLC determination of Erdosteine in bulk drug and pharmaceutical dosage form. J Pharm Bio Science 2013;3:105-9.

13. Kim HY, Chang KY, Lee HJ, Han SB, Lee KR. Sensitive determination of erdosteine in human plasma by use of automated 96-well solid-phase extraction and LC-MS/MS. J Pharm Biomed Analysis 2004;34:661-9.

14. Liu D, Wang Y, Tang YB, Chen XY, Zhong DF. Quantification of erdosteine in the low-volume of $\mathrm{dog}$ plasma by liquid chromatography tandem mass spectrometry. Chemical Research in Chinese Universities 2007;23:736-41.

15. Foster R. Organic Charge-Transfer Complexes, Academic Press, New York, 1969.

16. Zhao FL, Xu BZ, Zhang ZQ, Tong SY. Study on the charge-transfer reaction between 7,7,8,8-tetracyanoquinodimethane and drugs. J Pharm Biomedical Analysis 1999;21:355-60.

17. Al-Majed AA. Spectrophotometric estimation of D-penicillamine in bulk and dosage forms using 2,6-dichloroquinone-4-chlorimide (DCQ). J Pharm Biomedical Analysis 1999;21:827-33.

18. Mulliken RS, Person WB. Molecular Complexes. Journal of Molecular Structure 1969;10:155.

19. Job P. Formation and Stability of Inorganic Complexes in Solution. Annales de Chimie 1928;9:113-203.

20. ICH, In: International Conference on Harmonization of Technical Requirements for Registration of Pharmaceuticals for Human Use, Validation of Analytical Procedures: Text and Methodology Q2 (R1), 2005. 